\title{
Corticosteroids Administration for Enhancement of Fetal Lung Maturity and its Effects on Doppler Indices
}

\author{
MOUSTAFA H. HEGAB, M.D.; YAHIA A.S. WAFA, M.D. and HESHAM M. SWEELAM, M.Sc. \\ The Department of Obstetrics and Gynecology, Faculty of Medicine, Al-Azhar University, Cairo, Egypt
}

\begin{abstract}
Background: Evaluation the effects of maternal corticosteroids administration on Doppler indices (RI, PI \& S/D ratio) of umblical artery, fetal middle cerebral artery and fetal pulmonary trunk in third trimester and its correlation with pregnancy outcome.
\end{abstract}

Methods: One hundred and fourty (140) women were included in this study, and were divided in two groups, seventy (70) subjects as study group have a risk for preterm labour and seventy (70) subjects as control group with no risk of preterm labour, study group subjects received course of corticosteroids in third trimester. The Doppler examination of the Pulsatility Index (PI), Resistive Index (RI) and Systolic diastolic Ratio (S/D) of the Umbilical Artery (UA), the Middle Cerebral Artery (MCA) and Fetal Pulmonary Trunk (PT) were measured and comparison between values of both groups were done after zero, one, three and five weeks of corticosteroids administration of study group and same gestational age of control group.

Results: No significant change was observed in the mean values of the pulsatility, resistive indices and systolic-diastolic ratios of both groups in umbilical artery, fetal middle cerebral artery and fetal pulmonary trunk after one week after corticosteroids administration.

Conclusions: We demonstrated that dexamethasone administration did not cause changes in Doppler values and fetal biophysical profile scores after one week of its use.

Key Words: Corticosteroids - Doppler - Preterm birthBiophysical profile - Umbilical artery dopplerMiddle cerebral artery doppler - Pulmonary trunk doppler.

\section{Introduction}

PRETERM delivery is a leading cause of perinatal morbidity and mortality world wide and remains a significant problem in modern obstetrics [1]. Preterm infants are at risk for specific diseases

Correspondence to: Dr. Moustafa H. Hegab, The Department of Obstetrics and Gynecology, Faculty of Medicine, Al-Azhar University, Cairo, Egypt such as respiratory distress syndrome, intraventricular hemorrhage, broncho-pulmonary dysplasia, patent ductus arteriosus, necrotizing enterocolitis, sepsis, apnea and retinopathy [2]

Synthetic corticosteroids have been successfully employed for more than 20 years to enhance fetal lung maturity in saturations where preterm delivery is anticipated [3].

Maternal administration of synthetic corticosteroids (betamethasone or dexamethasone), for accelerating the maturity of the fetal lung, reduces neonatal mortality, respiratory distress syndrome, intraventricular haemorrhage and necrotizing enterocolitis in preterm infants [4]

Serious side-effects on the neonate have not been described when prenatal treatment has been administered during the second half of pregnancy (RCOG, 2004). However, a transient reduction of fetal heat rate variation and fetal body and breathing movements following maternal betamethasone administration was recently reported by [5]

Monitoring of biophysical activities is a powerful tool for the assessment of fetal wellbeing. Some studies have provided preliminary evidence that antenatal steroids given for enhancement of fetal lung maturity may induce a transient suppression of fetal biophysical activities [6]

In fact, conflicting results concerning the effects of betamethasone and dexamethasone on fetal heart pattern have been reported [7].

Recently, Scheepens et al., [8] found that betamethasone and dexamethasone was associated with an increase in long term and short term variability and decreased fetal movements on the first day after steroid administration followed by a decline in fetal heart rate variability on the second day. 
Similarly [9], the trial of reported a transient decrease in fetal heart variability and in fetal body and breathing movement after betamethasone, conversely, a rise in fetal heart rate variability was noted on the first day after dexamethasone.

Doppler ultrasound has been used to measure the blood flow velocity in vessels during the cardiac cycle in the fetoplacental, uteroplacental circulation and has been focused on arteries for the evaluation of downstream distribution of cardiac output [10]

Doppler velocimetry does not only facilitate judgment in diagnosis and monitoring of fetal wellbeing during pregnancy and labour but also has a role in the early detection of fetal hypoxia [11].

Evaluation of fetal well being with Doppler waveform studies after maternal corticosteroid administration is therefore important knowledge of fetal haemodynamic effects after exogenous corticosteroids is limited [12].

Doppler flow velocimetry of the umbilical, fetal cerebral circulation and fetal pulmonary trunk serves as another modality for the assessment of fetal status. This technique can be helpful in identifying the compromised fetus and could be of clinical value in the differential diagnosis between drug-induced changes in fetal biophysical behavior and those due to fetal compromise [13]

Furthermore, antenatal administration of corticosteroids, given to accelerate the development of fetal maturity and improve perinatal outcome in pregnancies at risk of preterm delivery, has been shown to upregulate placental expression and secretion of Corticotrophin Releasing Hormone $(\mathrm{CRH})$ which is a potent vasodilator of the fetal placental circulation, offering the possibility that corticosteroid treatment may alter placental blood flow [14]

\section{Patients and Methods}

This study was carried out at Obstetrics and Gynecology Department of Al-Hussien University Hospital from March 2015 to April 2017 on one hundred and forty (140) women with singleton pregnancies at a gestational age of 32 to 37 weeks divided into two groups. Group 1 : Seventy (70) subjects as study group have a risk for preterm labour. Group 2: Seventy (70) subjects as control group with no preterm labour.

Patient selection and inclusion criteria were, oral informed consent was obtained from all par- ticipating women, at the time of initial scanning all pregnancies had normal umbilical artery flow velocity waveforms values, preterm birth was anticipated on the basis of: History of previous preterm birth, preterm contractions of the uterus, history of recurrent spontaneous abortion, placenta previa and third trimester bleeding, preterm premature rupture of the membranes, polyhydramnios, patients with possible need for early termination of pregnancy including those with history of previous uterine rupture and hysterotomy.

Exclusion criteria were: Pregnancies with infants with major fetal structural malformations, women on corticosteroids treatment for another disease, any associated medical problem with pregnancy, patient's refusal.

An informed written consent was signed by every subject in study and control group. All patients enrolled in this study were subjected to full medical examination including general examination, local examination and special investigation (non stress test), intramuscular dexamethasone was given to group 1 subjects of the study following the setting protocol as 4 doses dexamethasone $(6 \mathrm{mg} / 12$ hours for $48 \mathrm{hrs})$, doppler ultrasound assessment of Umbilical (UA), fetal Middle Cerebral Artery (MCA) and fetal Pulmonary Trunk (PT) was carried out for all subjects in this study, using trans-abdominal probe $2.5: 5 \mathrm{MHz}$ (Esaote C. class \& Philips, clear, Vue, 350, C5-2), and evaluation of the pregnancy outcome as regards Apgar score, fetal birth and admission to NICU was done.

Evaluation of study group was done before (day 0$)$ and after $(1,3,5$ weeks) of first dose of dexamethasone administration [15] by modified biophysical profile, doppler blood flow from Umbilical Artery (UA), fetal Middle Cerebral Artery (MCA) and fetal Pulmonary Trunk (PT) according to [4] .

The examination was performed in a supine, slightly left lateral tilted position through the examination to avoid supine hypotension. Ultrasonographic and doppler Flow Velocity Waveforms (FVW) studies were done with pulsed-wave doppler after real time color flow localization of the fetal umbilical, middle cerebral arteries and pulmonary trunk [4]

\section{Statistical analysis:}

All the data collected were subjected to thorough statistical analysis. 


\section{Results}

Table (1): Comparison between 2 groups according to characteristics.

\begin{tabular}{lllll}
\hline Characteristics & \multicolumn{1}{c}{ Study } & Control & $\begin{array}{c}t- \\
\text { test }\end{array}$ & $\begin{array}{c}p- \\
\text { value }\end{array}$ \\
\hline $\begin{array}{l}\text { Age (years): } \\
\quad \text { Mean } \pm \text { SD }\end{array}$ & $28.21 \pm 3.35$ & $28.86 \pm 3.37$ & 1.378 & 0.242 \\
$\quad$ Range & $20-36$ & $20-36$ & & \\
Parity: & & & & \\
$\quad$ PG & $18(24.7 \%)$ & $22(30.6 \%)$ & 1.033 & 0.793 \\
P1 & $35(47.9 \%)$ & $29(40.3 \%)$ & & \\
P2 & $14(19.2 \%)$ & $14(19.4 \%)$ & & \\
P3 & $6(8.2 \%)$ & $7(9.7 \%)$ & & \\
H. PTL: & & & & \\
Yes & $11(15.1 \%)$ & $3(4.2 \%)$ & 4.939 & 0.026 \\
No & $62(84.9 \%)$ & $69(95.8 \%)$ & & \\
\hline
\end{tabular}

This table shows statistically significant difference between groups according to H. PTL.

Table (2): Comparison between study and control according to UA in all period of this study.

\begin{tabular}{lllll}
\hline UA & Study & Control & $\begin{array}{c}t- \\
\text { test }\end{array}$ & $\begin{array}{c}p \text { - } \\
\text { value }\end{array}$ \\
\hline$R I:$ & & & & \\
$\quad$ Mean \pm SD & $0.64 \pm 0.02$ & $0.63 \pm 0.05$ & 1.772 & 0.266 \\
$\quad$ Range & $0.58-0.69$ & $0.58-0.69$ & & \\
$P I:$ & & & & \\
$\quad$ Mean \pm SD & $0.94 \pm 0.07$ & $0.94 \pm 0.04$ & 1.016 & 0.152 \\
$\quad$ Range & $0.88-1.11$ & $0.88-1.11$ & & \\
S/D ratio: & & & & \\
$\quad$ Mean \pm SD & $2.61 \pm 0.16$ & $2.56 \pm 0.16$ & 1.855 & 0.278 \\
$\quad$ Range & $2.27-2.91$ & $2.27-2.91$ & & \\
\hline
\end{tabular}

This table shows no statistically significant difference between groups according to UA.

Table (3): Comparison between study and control according to MCA in all period of this study.

\begin{tabular}{lcccc}
\hline MCA & Study & Control & $\begin{array}{c}t \text { - } \\
\text { test }\end{array}$ & $\begin{array}{c}p \text { - } \\
\text { value }\end{array}$ \\
\hline RI: & & & & \\
$\quad$ Mean \pm SD & $0.76 \pm 0.04$ & $0.75 \pm 0.04$ & 1.431 & 0.215 \\
$\quad$ Range & $0.67-0.85$ & $0.67-0.85$ & & \\
PI: & & & & \\
$\quad$ Mean \pm SD & $1.71 \pm 0.19$ & $1.68 \pm 0.15$ & 0.669 & 0.100 \\
$\quad$ Range & $1.43-2.15$ & $1.43-2.15$ & & \\
S/D ratio: & & & & \\
$\quad$ Mean \pm SD & $5.56 \pm 0.55$ & $5.42 \pm 0.53$ & 0.815 & 0.122 \\
$\quad$ Range & $4.34-7.11$ & $4.34-7.11$ & & \\
\hline
\end{tabular}

This table shows no statistically significant difference between groups according to MCA.
Table (4): Comparison between study and control according to PT in all period of this study.

\begin{tabular}{lcccc}
\hline PT & Study & Control & $\begin{array}{c}t- \\
\text { test }\end{array}$ & $\begin{array}{c}p \text { - } \\
\text { value }\end{array}$ \\
\hline$R I:$ & & & & \\
$\quad$ Mean \pm SD & $0.86 \pm 0.09$ & $0.84 \pm 0.08$ & 1.008 & 0.151 \\
$\quad$ Range & $0.77-0.98$ & $0.77-0.98$ & & \\
$P I:$ & & & & \\
$\quad$ Mean \pm SD & $2.34 \pm 0.10$ & $2.31 \pm 0.10$ & 1.293 & 0.194 \\
$\quad$ Range & $2.18-2.51$ & $2.18-2.51$ & & \\
S/D ratio: & & & & \\
$\quad$ Mean \pm SD & $9.49 \pm 1.45$ & $9.18 \pm 1.37$ & 1.036 & 0.155 \\
$\quad$ Range & $6.18-11.11$ & $6.18-11.11$ & & \\
\hline
\end{tabular}

This table shows no statistically significant difference between groups according to PT.

Table (5): Comparison between $0,1,3,5$. Wk after corticosteroid administration according to UA in study group.

\begin{tabular}{llllllll}
\hline UA & Before & $\begin{array}{r}\text { 1st } \\
\text { wks. }\end{array}$ & $\begin{array}{c}\text { 3rd } \\
\text { wks. }\end{array}$ & $\begin{array}{c}5 \text { th } \\
\text { wks. }\end{array}$ & P1 & P2 & P3 \\
\hline • RI & $0.65 \pm$ & $0.65 \pm$ & $0.63 \pm$ & $0.61 \pm$ & 0.306 & 0.247 & 0.031 \\
& 0.02 & 0.02 & 0.02 & 0.01 & & & \\
$\bullet$ PI & $0.98 \pm$ & $0.97 \pm$ & $0.91 \pm$ & $0.90 \pm$ & 0.175 & 0.115 & 0.014 \\
& 0.04 & 0.04 & 0.10 & 0.02 & & & \\
• S/D & $2.73 \pm$ & $2.72 \pm$ & $2.53 \pm$ & $2.41 \pm$ & 0.320 & 0.140 & 0.018 \\
ratio & 0.09 & 0.09 & 0.07 & 0.06 & & & \\
\hline
\end{tabular}

P1: Difference between before and 1st wks.

P2: Difference between before and 3rd wks.

P3: Difference between before and 5th wks.

This table shows statistically significant difference between before and 5 th wks according to UA.

Table (6): Comparison between GA (wks) according to UA in control.

\begin{tabular}{lccccc}
\hline UA & 32wks. & 35wks. & 37wks. & P1 & P2 \\
\hline RI & $0.64 \pm 0.07$ & $0.63 \pm 0.02$ & $0.61 \pm 0.01$ & 0.294 & 0.039 \\
PI & $0.98 \pm 0.05$ & $0.94 \pm 0.02$ & $0.90 \pm 0.01$ & 0.158 & 0.028 \\
S/D ratio & $2.74 \pm 0.09$ & $2.53 \pm 0.07$ & $2.40 \pm 0.05$ & 0.125 & 0.010 \\
\hline
\end{tabular}

P1: Difference between 32wks and 35wks.

P2: Difference between 32wks and 37wks.

This table shows statistically significant difference between $32 \mathrm{wks}$ and $37 \mathrm{wks}$ according to UA.

Table (7): Comparison between $0,1,3,5 \mathrm{Wk}$ after corticosteroid administration according to MCA in study group.

\begin{tabular}{llllllll}
\hline MCA & Before & $\begin{array}{r}1 \text { st } \\
\text { wks. }\end{array}$ & $\begin{array}{c}\text { 3rd } \\
\text { wks. }\end{array}$ & $\begin{array}{c}5 \text { th } \\
\text { wks. }\end{array}$ & P1 & P2 & P3 \\
\hline - RI & $0.79 \pm$ & $0.79 \pm$ & $0.73 \pm$ & $0.71 \pm$ & 0.174 & 0.481 & 0.022 \\
& 0.04 & 0.03 & 0.02 & 0.02 & & & \\
- PI & $1.83 \pm$ & $1.80 \pm$ & $1.69 \pm$ & $1.46 \pm$ & 0.223 & 0.733 & 0.028 \\
& 0.12 & 0.21 & 0.16 & 0.06 & & & \\
- S/D & $5.96 \pm$ & $5.89 \pm$ & $5.66 \pm$ & $4.62 \pm$ & 0.178 & 0.598 & 0.022 \\
ratio & 0.32 & 0.55 & 0.25 & 0.24 & & & \\
\hline
\end{tabular}

P1: Difference between before and 1st wks.

P2: Difference between before and wks.

P3: Difference between before and 5th wks. 
This table shows statistically significant difference between before and 5 th wks. according to MCA.

Table (8): Comparison between GA (wks) according to MCA in control group.

\begin{tabular}{lccccc}
\hline MCA & 32wks. & 35wks. & 37wks. & P1 & P2 \\
\hline RI & $0.80 \pm 0.02$ & $0.75 \pm 0.02$ & $0.71 \pm 0.02$ & 0.311 & 0.037 \\
PI & $1.83 \pm 0.12$ & $1.70 \pm 0.09$ & $1.47 \pm 0.05$ & 0.189 & 0.020 \\
S/D ratio & $5.99 \pm 0.32$ & $5.64 \pm 0.25$ & $4.67 \pm 0.23$ & 0.138 & 0.016 \\
\hline
\end{tabular}

P1: Difference between $32 w k s$ and $35 w k s$.

P2: Difference between $32 \mathrm{wks}$ and $37 \mathrm{wks}$.

This table shows statistically significant difference between 32wks and 37wks according to MCA.

Table (9): Comparison between 0, 1, 3, 5Wk after corticosteroid administration according to PT in Study group.

\begin{tabular}{llllllll}
\hline PT & Before & $\begin{array}{r}\text { 1st } \\
\text { wks. }\end{array}$ & $\begin{array}{c}\text { 3rd } \\
\text { wks. }\end{array}$ & $\begin{array}{r}\text { 5th } \\
\text { wks. }\end{array}$ & P1 & P2 & P3 \\
\hline • RI & $0.90 \pm$ & $0.91 \pm$ & $0.84 \pm$ & $0.78 \pm$ & 0.312 & 0.294 & 0.012 \\
& 0.12 & 0.06 & 0.06 & 0.03 & & & \\
• PI & $2.41 \pm$ & $2.41 \pm$ & $2.30 \pm$ & $2.23 \pm$ & 0.227 & 0.158 & 0.026 \\
& 0.08 & 0.08 & 0.06 & 0.04 & & & \\
- S/D & 10.63 & 10.44 & $8.98 \pm$ & $7.73 \pm$ & 0.084 & 0.125 & 0.030 \\
ratio & \pm 0.46 & \pm 1.10 & 0.90 & 0.90 & & & \\
\hline
\end{tabular}

P1: Difference between before and 1st wks.

P2: Difference between before and 3rd wks.

P3: Difference between before and 5th wks.

This table shows statistically significant difference between before and 5 th wks. according to PT.

Table (10): Comparison between GA (wks) according to PT in control.

\begin{tabular}{lccccc}
\hline PT & 32wks. & 35wks. & 37wks. & P1 & P2 \\
\hline RI & $0.91 \pm 0.04$ & $0.84 \pm 0.05$ & $0.78 \pm 0.08$ & 0.273 & 0.038 \\
PI & $2.41 \pm 0.08$ & $2.30 \pm 0.06$ & $2.22 \pm 0.06$ & 0.286 & 0.022 \\
S/D ratio & $10.63 \pm 0.46$ & $9.07 \pm 0.89$ & $7.83 \pm 0.84$ & 0.358 & 0.040 \\
\hline
\end{tabular}

P1: Difference between $32 w k s$ and $35 w k s$.

P2: Difference between 32wks and 37wks.

This table shows statistically significant difference between $32 \mathrm{wks}$ and $37 \mathrm{wks}$ according to PT.

Table (11): Comparison between study and control according to Apgar score.

\begin{tabular}{lllll}
\hline Apgar score & Study & Control & $t$-test & $p$-value \\
\hline $\begin{array}{l}\text { Imin: } \\
\text { Median (QR) }\end{array}$ & $6(4)$ & $6(3)$ & 0.017 & 0.898 \\
$\quad$ Range & $3-9$ & $3-8$ & & \\
5min: & & & & \\
$\quad$ Median (QR) & $7(2)$ & $7(1.75)$ & 0.417 & 0.520 \\
$\quad$ Range & $4-9$ & $4-9$ & & \\
10min: & & & & \\
$\quad$ Median (QR) & $8(3)$ & $8(1)$ & 1.459 & 0.271 \\
$\quad$ Range & $5-9$ & $4-9$ & & \\
60min: & & & & \\
$\quad$ Median (QR) & $9(1)$ & $9(1)$ & 1.743 & 0.197 \\
$\quad$ Range & $6-10$ & $6-10$ & & \\
\hline
\end{tabular}

This table shows no statistically significant difference between groups according to Apgar score.

Table (12): Comparison between study and control according to fetal weight and M. BPP

\begin{tabular}{lllll}
\hline & Study & Control & $t$-test & $p$-value \\
\hline Fetal weight: & & & & \\
Mean \pm SD & $2264.85 \pm 382.83$ & $2357.55 \pm 428.75$ & 6.426 & 0.012 \\
Range & $1390-3150$ & $1420-3110$ & & \\
M.BPP: & & & & \\
Mean \pm SD & $7.72 \pm 0.70$ & $7.74 \pm 0.67$ & 0.117 & 0.732 \\
Range & $6-8$ & $6-8$ & & \\
\hline
\end{tabular}

This table shows statistically significant difference between groups according to fetal weight.

Table (13): Comparison between study and control according to NICU.

\begin{tabular}{lcccr}
\hline NICU & Study & Control & $t$-test & $p$-value \\
\hline Yes & $36(49.3 \%)$ & $32(44.4 \%)$ & 0.345 & 0.557 \\
No & $37(50.7 \%)$ & $40(55.6 \%)$ & & \\
\hline Total & $73(100 \%)$ & $72(100 \%)$ & & \\
\hline
\end{tabular}

This table shows no statistically significant difference between groups according to NICU.

\section{Discussion}

In this study Seventy study group women were subjected to standard dose of dexamethasone, followed by ultrasonographic assessment of fetal biophysical activities, fetal weight and doppler studies (pulsatility, resistive indices and systolicdiastolic ratios) for umbilical artery, fetal middle cerebral artery and fetal pulmonary trunk on baseline, and after one, three and five weeks of administration, also same ultrasonographic assessment and same doppler indices were done for seventy control group women at thirty two, thirty five and thirty seven weeks of gestation.

In a study performed by Rotmensch et al. [16], no change was observed on the biophysical profile scores after one week of steroid use. In this study, it was also observed that administrating dexamethasone for the mother did not lead to a significant decrease of biophysical profile scores in healthy preterm fetuses after one week, and no statistical significant difference of biophysical profile scores between both groups in same gestational age.

Jackson et al., [17] showed that the administration of dexamethasone decreases fetal movement and breathing and as a result the biophysical profile scores may be decreased. In their study, amniotic fluid was also decreased, but this result was not obtained in our study. 
In the current study, there was not a statistically significant difference in the frequency of the findings in the pre-compared to post-dexamethasone measurements of modified biophysical profile score of the study patients, and also no statistical significant difference of biophysical profile scores between control group and study group patients and none of the biophysical profile scores was $<6$.

Another modality for evaluation of the fetal status is doppler velocimetry of the umbilical, fetal cerebral circulation and fetal pulmonary trunk [18] In a previous study carried out by [19], corticosteroids had no effect on doppler indices obtained from fetal middle cerebral artery, placental arteries or fetal pulmonary trunk. This findings has been subsequently confirmed by [20], and with our study.

In a study done by Ustunyurt et al., [15] they noticed that the doppler indices after one week of administration were similar to those before treatment, and that also was noticed in our study group patients after one week of administration, and when these doppler values were compared with values of control group patients at the same gestational age no statistical significant difference were noticed.

Also when comparing doppler results of control and study patients obtained from umbilical, fetal middle cerebral arteries and fetal pulmonary trunk all over the period of study no statistical significant difference were noticed and and when comparing results of third week after steroid in study group with results of $35^{\text {th }}$ week in control group no statistical significant difference was noticed and thus was also noticed between results of $37^{\text {th }}$ week and results of $5^{\text {th }}$ week after steroid use.

But when comparing doppler results of before and 1 st week of steroid use with $5^{\text {th }}$ week results of study group there was a statistical significant difference was noticed, this significance was also noticed when comparing doppler results of 32 nd week with results of $37^{\text {th }}$ week in control group.

This significance may be explained by the overall increase in placental size and associated increase in number of chorionic villi throughout pregnancy which result in an expansion of the distal vascular pool of the umbilical artery, characterized with a decreasing values of vascular resistance [10].

Yalti et al., [21] stated that umbilical velocimetry, is a test of placental function that does not always directly reflect fetal status.
Piazze et al., [22] and Urban et al., [23] added that there was no significant change observed in UA PI through administration of corticosteroids whether dexamethasone or betamethasone therapy. That is in accordance with the current study where no significant change was detected.

In the current study there was no significant changes in the mean values of the pulsatility, resistive indices, systolic-diastolic ratios or maximum velocity of flow in umbilical, fetal middle cerebral arteries and fetal pulmonary trunk pre and post corticosteroid injection in study group, and also no significant changes between control and study group values of same doppler indices for same vessels when compared in the same gestational age.

Kim et al., [24] observed doppler in fetuses which developed respiratory distress syndrome, in current study we follow-up pregnancy outcome of both groups by Apgar score and need to neonatal Intensive Care Unit admission, it was observed that no statistical significant difference in Apgar scores after one, five, ten and sixty minutes of delivery between study and control groups, and also no statistical significant difference between both groups in need for Neonatal Intensive Care Unit admission contrary to Kim et al., 2013.

Ustunyurt et al., [15] evaluated the effects of maternal corticosteroid administration on fetal MPA, significant changes in PI and RI were found 1 day and 2 days after corticosteroid administration. But after 7 days of treatment, the waveforms returned to the type of waveform found before treatment.

Thuring et al., [25] evaluated the effects of maternal corticosteroid administration on fetal and uteroplacental circulation in pregnancies at risk of preterm delivery, significant changes in PI and RI of both umbilical artery and fetal middle cerebral artery within $24 \mathrm{~h}$ following corticosteroid therapy and maintained for up to $48 \mathrm{~h}$. But after 7 days of treatment the doppler results returned to the values before treatment.

\section{Conclusion:}

We demonstrated that dexamethasone administration did not cause changes in fetal biophysical profile scores after one week of its use.

No significant changes in the mean values of the doppler indices of umbilical, fetal middle cerebral arteries and fetal pulmonary trunk after one week of corticosteroid injection and also no significant changes between control and study 
group values of same doppler indices for same vessels when compared in the same gestational age.

\section{References}

1- ARDUINI D., RIZZO G. and FOUI G.: Prediction of fetal outcome small for estational age Doppler measurement obtained from different fetal vessels. J. Perinatal. Med., 20: 29-38, 2009.

2- MERCER B.M., GOLDENBERG R.L. and MOAWAD A.H.: "The preterm prediction study: Effect of gestational age and cause of preterm birth on subsequent obstetric outcome". American Journal of Obstetrics and Gynecology, 181 (5 Pt 1): 1216-21. Doi:10.1016/S0002-9378(99)701110. PMID 10561648, 1999.

3- COHLEN B.J., STIGTER R.H., DERKS J.B., MULDER E.J. and VISSER G.H.: Absence of significant hemodynamic changes in the fetus following maternal bethamethasone administration. Ultrasound Obstet. Gynecol., 8 (4): 252-5, 2006.

4- CHIRIT Y., CAUBEL P., HERRERO R. and SCHWINTE A.L.: Effect of maternal dexamethasone administration on fetal Doppler flow velocity wave forms. Br. J. Obstet. Gynecol., 107 (4): 501-7, 2011.

5- NEILSON Z.: The effect of a prolonged time interval between antenatal corticosteroids administration and delivery on outcome in preterm neonates: A cohort study, 2014.

6- THILAGANATHAN B., ROBERTS N. and SEBRINE N.J.: Role of ultrasound in obstetrics, symposium. Obstet. Gynecol., and Reproductive Medicine, 17: 3, 2006.

7- WAFFISCH A.S., BAJAJ K. and KUMAR P.: The effect $\mathrm{f}$ the time interval from antenatal corticosteroid exposure to delivery on antenatal outcome of very low birth weight infants. Am. J Obstet. Gynecol, 191: 1409-13, 2011.

8- SCHEEPENS L.A., MAGEE G.S. and MOULDAN M.: A randomized controlled comparison of betamethasone with dexamethasone: Effect on antenatal fetal heart rate. Br. J. Obstet. Gynecol., 104 (11): 1233-8, 2013.

9- MILLER D.A., MULDER E.J. and DERKS J.B.: Transient reduction in fetal activity and heart rate variation after maternal betamethasone and dexamethasone administration. Am. J. Obstet. Gynecol., 104 (11): 1239-47, 2014.

10- GAGNON and VANDEN HOF: Doppler ultrasound in obstetric and gynecology. New York: Raven Press, 2013.

11- BASCHAT A.A.: Arterial and venous Doppler in the diagnosis and management of early onset fetal growth restriction. Early Hum. Dev., 81: 877-87, 2015.

12- WANG S.S., TIAN X.Y., YAN H.W. and ZHENG X.Y.: Prenatal assessment of pulmonary maturity on 3-D ultrasound: J. Obstet. Gynaecol. Res., Sep., 42 (9): 1086-93. doi:10.1111/jog.13006. Epub 2016 May 11, 2016.
13- BASCHAT A.A., GEMBRUCH U. and HARMAN C.R.: The relationship between arterial and venous Doppler and perinatal outcome in fetal growth restriction. Ultrasound Obstet. Gynecol., 16: 407-13, 2016.

14- WALLACE E.M. and BAKER L.S.: Effect of antenatal betamethasone administration on placental vascular resistance. Lancet, 353: 1404-7, 2009.

15- USTUNYURT O.B., USTUNYURT E., KORKMAZER E. and ALTUG N.: The effect of maternal betamethasone administration on Doppler flow velocity parameters of the fetal branch pulmonary artery: J. Obstet. Gynaecol., Aug., 34 (6): 489-91. doi: 10.3109/01443615.2014.914479. Epub 2014 May 15, 2014.

16- ROTMENSCH S., LIBERATI M. and CELENANO C.: The effect of betamethasone on fetal biophysical activities and Doppler velocimetry of umbilical and middle cerebral arteries. Acta Obstet. Gynecol. Scand., 78 (9): 768-73, 2009.

17- JACKSON R., LAMBU F.A. and RAMIN S.M.: Effect of betamethasone and dexamethasone administration antenatal on fetal heart rate. Br. J. Obstet. Gynecol., 91: 1211-7, 2013.

18- CUNNINGHAM F.G., WILLIAMS J.W., LEVENO K.J., BLOOM S. and HAUTH J.C. WILLIAMS: Obstetrics, 23rd ed. p. 821-2, 2001.

19- CROWLEY P., CHALMERS I. and KEIRSE MARC J.N.C.: The effects of corticosteroid administration before preterm delivery: An overview of the evidence from controlled trials. Br. J. Obstet. Gynaecol., 97: 11-25, 1990.

20- KÄHLER C., SCHLEUSSNER E., MOLLER A. and SEEWALD H.J.: Doppler measurements in fetoplacental vessels after maternal betamethasone administration. Jan.Feb., 19 (1): 52-7, 2014.

21- YALTI S., ORAL O. and GURBUZ B.: Ratio of middle cerebral to umbilical artery blood velocity in pre-eclamptic, and hypertensive women in the prediction of poor perinatal outcome. Indian J. Med. Res., 120: 44-50, 2011.

22- PIAZZE J.J., ANCOSCHI M.M. and TORRE R.L.: Effect of antenatal betametasone therapy on maternal. Fetal Doppler Velocimetry. Early Human Development, 60: 225-32, 2011

23- URBAN R., LEMANCEWICZ A. and PRZEPIESC J.: Antenatal corticosteroid therapy: A comparative study of dexamethasone and betamethasone effects on fetal Doppler flow velocity wave forms. Europ. J. Obstet. Gynecol. and Reprod. Biology, 120: 170, 2011.

24- KIM S.Y., KHANDELWAL M. and GAUGHAN J.P.: Is the intrapartum biophysical profile useful. Am. College of Obstet. and Gynecol., 102: 471-6, 2013.

25- THURING A., MALCUS P. and MARSAL K.: Effect of maternal betamethasone on fetal and uteroplacental blood flow velocity waveforms. Ultrasound Obstet. Gynecol., 37 (6): 668-72, 2011. 


\section{تآثيرتناول الآم للستيرويدات القشرية

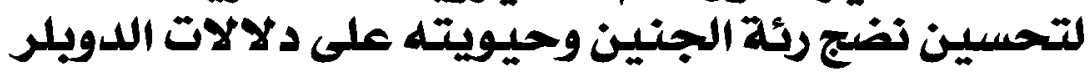

على الرغم من التقدم الذى حدث فى رعاية الحمل ورعاية الآطفال حديثى الولادة فإن متلازمة الضائقة التنفسية مازالت السبب الرئيسى التدهور الصحة والوفاة فى الآطفال المبتسرين.

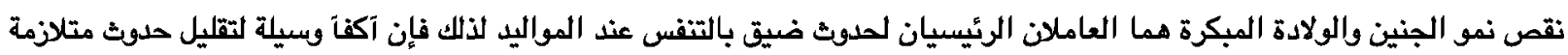

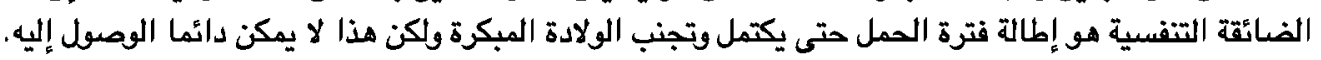

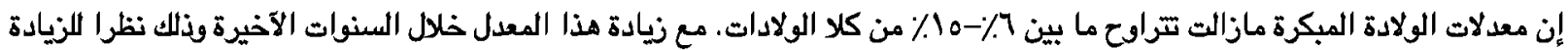

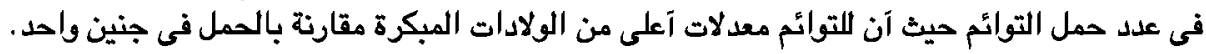

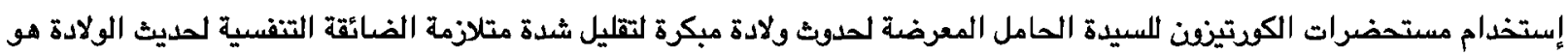

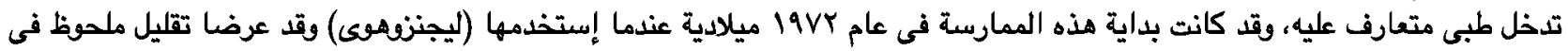

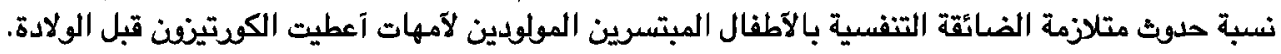

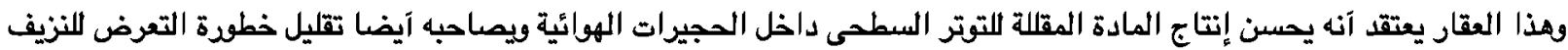

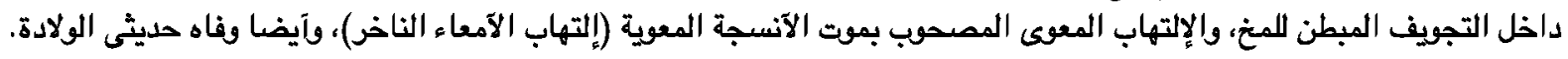

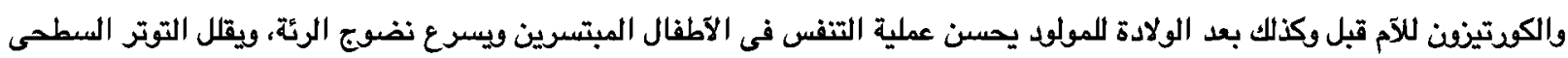

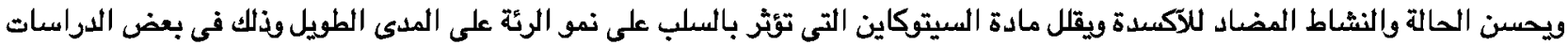
التى آجريت على الحيوانات.

إن الديكساميثانفن والييتاميثانفن نوعان من الكوتينون يعبران المشيمة بسهولة ولذا يستخدمان لعلاج الآجنة، وقد آظهرث دراسات سابقة

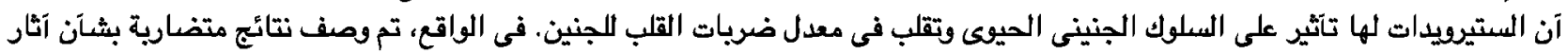

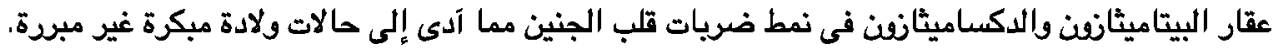

هدف البحث:

تقييم آثار تناول الآمهات الديكساميثانفذ على السلوك الجنينى الحيوى وسرعة تدفق موجات الدوبلر فى حالات الحمل الطبيعى المعرضه اللولادة المبكرة ونتائج الولاده. طريقّة البحث:

تم إجراء هذه الدراسة فى قسم النساء والتوليد بمستشفى الصسين الجامعى على مئّ وآربعين (•ع (ا)) حالة ذوىى حمل لجنين واحد ما بين

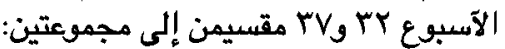

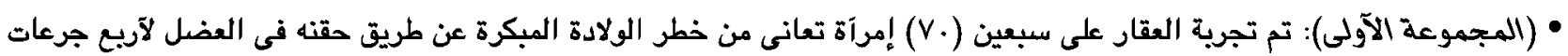

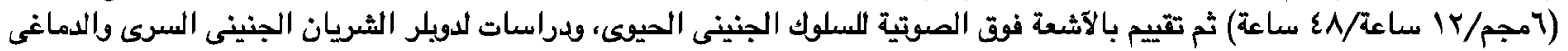

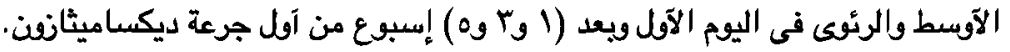

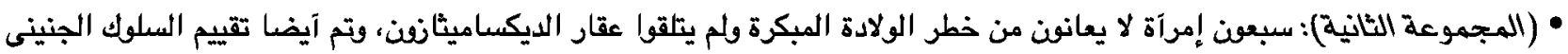

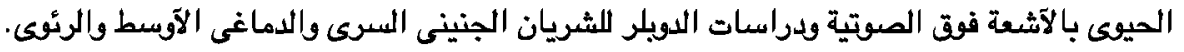

$$
\text { • وتم مقارنة نتائج المجموعتين ومتابعة تآثير العقار على نتائج الولادة. }
$$

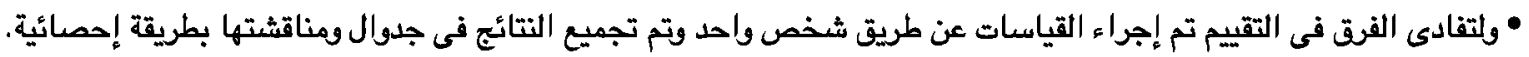
نتائج البحث: • لعقار الديكساميثانون تآثير قوى وإن كان مؤقت على التفس وحركات الجذع والآطراف، مما آدى إلى إنخفاض درجة السلوك الجنينى الحيوى.

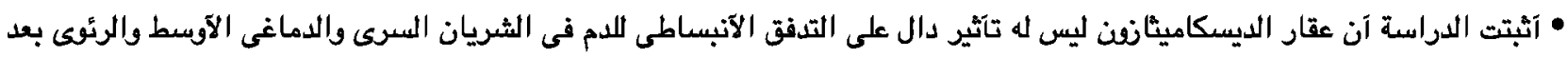
إسبوع من إستخدامه. 